\title{
Tibetan Buddhism in the Digital Age: Exploring Online Buddhist Study, Practice, and Community on Ocean: The V ast Teachings of Chögyam Trungpa
}

\author{
Eben Yonnetti \\ Department of Religious Studies \\ University of Colorado Boulder
}

\begin{abstract}
:
This article investigates the growth of online religion through a study of Ocean: The $V$ ast Teachings of Chögyam Trungpa. Opened to the public in the spring of 2015 with a series of courses, practices, and gatherings, Ocean describes itself as an online site of practice, study, and community dedicated to the life and teachings of the Tibetan Buddhist reincarnate teacher Chögyam Trungpa Rinpoche (1939/40-1987). Closely examining Ocean's history, design, and programs, I illustrate how Ocean exemplifies a shift from religion online primarily comprised of individuals consuming information toward the increasing presence of spaces that support more participatory, accessible, and interactive relationships among their users. I draw upon Heidi Campbell's concept of "networked religion," to examine Ocean as a novel space for the study and practice of Tibetan Buddhism that is both becoming entangled with users' offline religious lives and practices and a new site for the negotiation of participation and authority.
\end{abstract}

Keywords: Online religion, religious authority, Tibetan Buddhism, Chögyam Trungpa Rinpoche, Shambhala 
On Saturday, April 18, 2015 a group of thirty-two individuals gathered to collectively recite and practice Chögyam Trungpa Rinpoche’s Sädhana of Mahämudrā. This Buddhist liturgical practice has been continuously performed in communities and by individual vajrayāna practitioners internationally on new moons, full moons, and on other holidays celebrated by the Shambhala community ever since Trungpa Rinpoche introduced it in 1968. What made this particular group's practice so unusual was the geographic representation of the participants who came from across two continents and five time zones to enact this ritual together online in an interactive digital 'shrine room.' The medium for this gathering was the newly launched website Ocean: The V ast Teachings of Chögyam Trungpa (henceforth Ocean).

Opened to the public in January of $2015,{ }^{1}$ Ocean describes itself as an online site of practice, study, and community dedicated to the life and teachings of the Tibetan Buddhist reincarnate teacher Chögyam Trungpa Rinpoche (1939/40-1987). ${ }^{2}$ Not officially associated with the organization of Shambhala International or its current leader, Sakyong Mipham Rinpoche, ${ }^{3}$ Ocean's mission is to "further the study and practice of Chögyam Trungpa's teachings, and to nurture community amongst old and new students alike." ${ }^{4}$ Founded by Walter and Joanne Fordham as a daughtersite to their Halifax, NS, based website The Chronicles of Chögyam Trungpa Rinpoche (henceforth referred to as The Chronicles), Ocean provides a platform for The Chronicles'

\footnotetext{
1 "Ocean: The Vast Teachings of Chögyam Trungpa Rinpoche," The Chronicles of Chögyam Trungpa Rinpoche, 20 November 2014, accessed 20 April 2015, http://chronicleproject.com/stories 435a.html.

2 "Home," Ocean: The Vast Teachings of Chögyam Trungpa, Chronicles Network, accessed 20 April 2015, http://ocean.chronicleproject.com.

${ }^{3}$ The legacy of Chögyam Trungpa Rinpoche is complex, to say the least. Although he founded the organization that is today Shambhala International (formerly Vajradhatu International) in 1973, there are also a number of semi- and loosely-associated organizations, as well as other completely independent groups that claim to carry on Trungpa Rinpoche's work and teachings. While certainly an interesting and highly politicized topic to explore, a detailed examination of the history of Shambhala and other groups is beyond the scope of this paper. For the purposes of this article, it is important to note that The Chronicles and Ocean are not officially associated with Shambhala International, but still maintain various ties to the broader organization. Users of Ocean and The Chronicles vary in their involvement with Shambhala International and other organizations, as will be discussed below. Unless specified as 'Shambhala International,' the term 'Shambhala' for this paper shall refer broadly to the body of Trungpa Rinpoche's teachings and to all individuals who identify as following them.

4 "About: Mission," Ocean: The Vast Teachings of Chögyam Trungpa, Chronicles Network, accessed 20 April 2015, http://ocean.chronicleproject.com/about/mission/.
} 
diverse community to gather for collective study and practice. In addition to The Chronicles vast database, Ocean offers live, interactive web-based classes, group practices, and a member's section with individual profiles.

This paper examines Ocean as an online site of religious study, practice, and community. After a brief overview of religious practice and community online, I examine online religion on Ocean through a discussion of the site's history, design, and programs, as well as personal experiences conducting limited participant observation from March 24-April 18, 2015. In doing so, I illustrate how Ocean illustrates a shift identified by sociologist Christopher Helland, ${ }^{5}$ from religion online primarily comprised of individuals consuming information toward an increasing number of spaces that support more participatory, accessible, and interactive relationships among their users. In this way, I draw upon Heidi Campbell's concept of "networked religion," to examine Ocean as a novel online venue for the study and practice of 'Tibetan Buddhism that is becoming increasingly entangled with users' offline religious lives and practices. Yet, while the internet is often assumed to be an inherently democratic and participatory space, allowing users to access greater amounts of information, I also argue that such expectations are not necessarily true in that users and content are still managed by online authorities and participation is channeled through and limited by the capabilities of a given platform.

With individuals' participation in communities on the internet increasingly blurring the distinction between on- and offline spaces, Campbell describes "networked religion" as the ways in which "religious experience, belief, and practice are lived out online" in such a way that "social relationships, structures, and patterns of belief become highly malleable, global, and interconnected." " In this way, online religion is part of a broader global shift toward increasingly decentralized,

\footnotetext{
${ }^{5}$ Christopher Helland, "Online Religion as Lived Religion: Methodological Issues in the Study of Religious Participation on the Internet," in "Special Issue on Theory and Methodology," ed. Oliver Krüger, special edition, Heidelberg Journal of Religions on the Internet 1, no. 1 (2005): 1-16.

${ }^{6}$ Heidi A Campbell, "Understanding the Relationship between Religion Online and Offline in a Networked Society," Journal of the American Academy of Religion 80, no. 1 (March 2012): 6493.

${ }^{7}$ Ibid., 65 .

${ }^{8}$ Ibid., 68.
} 
interconnected, and instantaneous communication and interaction. Campbell presents the image of a network as useful for understanding the "complex interplay and negotiations occurring between the individual and the community, new and old sources of authority, and public and private identities in a networked society." In other words, thinking about religion as 'networked' helps to illustrate how religious lives, practices, and authorities on- and offline inform, interact, and impact each other.

Furthermore, Campbell argues that studying religions as networks can shed light on how religion online is not necessarily its own entity, as distinguished from religion offline, but rather is reflective of and a lens into broader trends in an increasingly globalized and complex offline religious culture. Thus, Campbell writes, the study of religion online "provides an interesting and important microcosm for studying trends within religious practice and meaning making in society." analyzing this final point on Ocean would require a much deeper level of ethnographic engagement with the community, I will argue below that the dynamics of authority, access, and participation are three areas that bridge online religious communities with negotiations occurring offline.

In 1999, Helland articulated a distinction between religion online, which was limited to mere information dissemination and consumption (e.g. a dharma center webpage), and online religion, which was participatory and involved individuals using the internet for religious practice (e.g. attending a Buddhist temple in Second Life). ${ }^{11}$ Later, Helland modified this idea from a dichotomy to a spectrum, which includes a wide range of possibilities inclusive of both information and participatory elements. ${ }^{12}$ The reality of the internet today, he asserts, is more complex as numerous religious websites "incorporate both an information zone and interaction zone in a single site." 13 This is true on Ocean, for example, which not only provides information and

\footnotetext{
${ }^{9}$ Ibid., 65.

${ }^{10}$ Ibid., 66.

${ }^{11}$ Christopher Helland, "Online Religion/Religion Online and Virtual Communities," in Religion on the Internet: Research Prospects and Promises, Religion and the Social Order, ed. D. E. Cowan and J. K. Hadden (New York: JAI Press, 2000).

12 Helland, "Online Religion as Lived Religion," 2.

13 Ibid., 13.
} 
study materials, but also has various possibilities for social-media like interaction, such as commenting on and sharing files, as well as directly engaging other practitioners through forums, and practices and classes connected with live voice and video technologies. However, as shall be illustrated below, internet technologies can also be used by practitioners in numerous ways for various levels of engagement with online communities. Using Helland's spectrum, the next section examines how The Chronicles' space of religion online shifted to a form of online religion, a digital space with more participatory capabilities and communal practice, with the development of Ocean.

The Chronicles was launched in 2002 to serve as a clearinghouse for all manner of materials related to Chögyam Trungpa Rinpoche. Its pages, which are available to the public and do not require an account or user fee, include a wealth of photographs, transcripts, audio, and video files of Trungpa Rinpoche's teachings. It also archives students' and other Buddhist teachers' recollections of encounters with Trungpa Rinpoche, interviews with some of his former students, tributes to community members recently passed away, and news on various topics from the Shambhala community and other Tibetan Buddhist teachers.

The Chronicles contains two pages that are somewhat interactive in so far as they can incorporate user comments. "Brief Encounters"14 contains short recollections by students and acquaintances of meetings with Trungpa Rinpoche, and "Parasangha Tribute" ${ }^{15}$ offers thoughts from other Buddhist teachers as well as all manner of poems, notes, songs, and other tributes submitted in memory of Trungpa Rinpoche. It is important to note that these pages require users to submit a comment to a Chronicles email address before it can be posted. Thus, the level of participation is limited and mediated by the filtering authority of The Chronicles webmaster(s). The level of direct online interaction among site users is minimal and user participation is generally limited to the consumption of content provided by the site's administrators.

\footnotetext{
14 “Brief Encounters," The Chronicles of Chögyam Trungpa Rinpoche, accessed 20 April 2015, http://chronicleproject.com/brief.html.

15 "Parasangha Tribute Page," The Chronicles of Chögyam Trungpa Rinpoche, accessed 20 April 2015, http://www.chronicleproject.com/tribute.html.
} 
Citing visitors from more than fifty countries and monthly traffic of more than 10,000 unique hits, ${ }^{16}$ The Chronicles convened a gathering of members of its community in Halifax, NS, in late 2011 to brainstorm ways to expand the work of The Chronicles to an ever increasing global audience and to make it more interactive. ${ }^{17}$ As Walter Fordham described, “The Chronicles turns ten in 2012, and it's time for a fresh look at who we are, and where we're going." 18 He continued "The Chronicles would like to host a space where our diverse clan can gather, debrief, appreciate one another's paths, learn from each other, and go deeper into Chögyam Trungpa's cornucopia of dharma." 19 As internet capabilities have evolved since its founding, The Chronicles sought to expand its work into a more interactive online venue.

Noting especially the gap in opportunities for community participation and interaction on The Chronicles, Walter Fordham further explains in a call for participation on The Chronicles website,

Please join us. The Inner Chronicles [the original name proposed for this interactive digital space] will be an online social/sangha network, that could also spur face-to-face gatherings. In this space we can share our individual experience, form groups, collaborate on projects, study the dharma, and practice together. Do we know exactly what form this will take? No. But we'll create it together. ${ }^{20}$

In late 2012, development of a community-oriented web-interface began and the first public announcement was made on November 25, 2013. In addition to screenshots and a call for a small number of beta testers, the communication unveiled a new name for the proposed website: Ocean: The V ast Teachings of Chögyam Trungpa. ${ }^{21}$

One year later, on November 20, 2014, another announcement was posted, calling for participants in Ocean's first three pilot classes, which would open in

\footnotetext{
${ }^{16}$ Ibid.

17 "Exploring the Inner Chronicles," The Chronicles of Chögyam Trungpa Rinpoche, 3 January 2012, accessed 20 April 2015, http://www.chronicleproject.com/stories_329.html.

${ }^{18}$ Ibid.

${ }^{19}$ Ibid.

${ }^{20}$ Ibid.

21 "Announcing Ocean: The Vast Teachings of Chögyam Trungpa," The Chronicles of Chögyam Trungpa Rinpoche, 25 November 2013, accessed 20 April 2015, http://www.trungpa.com/stories $435 . \mathrm{html}$.
} 
January 2015. Each course was to be four weeks in duration and have a maximum of 25 participants. The long-term vision for Ocean expressed in the announcement was to incrementally develop a rich and supportive space for practice and study among beginners as well as advanced tantric practitioners. The announcement also stressed that part of its long-term vision was to facilitate "real-world gatherings to study, practice, and celebrate the dharma." 22 Echoing Campbell's argument that online religious practice supplements rather than replaces offline practice, ${ }^{23}$ Ocean was presented by its organizers as a space to augment, rather than to replace offline religious practice. Shortly after Shambhala Day (February 19) 2015, Ocean was officially launched with another announcement on The Chronicles' website and email listserv. The digital space was opened for the public to create accounts, sign up for classes and practice groups, and take advantage of the various PDF transcripts, video and audio recordings in the resources menu.

Following scholar of digital religion Gregory Grieve, who argues that a research field site "can no longer be defined merely as a geographic place," ${ }^{24}$ I took this project as an opportunity to conduct limited virtual fieldwork. Between March 24 and April 18, 2015, I participated in Ocean as a registered user via an Open House, an intermediate class, as well as an online practice, all of which will be described below. It should be noted, however, that while I engaged in participant observation, involving engagement and thick description, I did not conduct any qualitative interviews during this time.

Creating an Ocean account was free and aside from a request for voluntary contributions, there was no use fee for the site. Ocean classes and practices could be accessed either via a toll-free number or through live video conferencing. The latter used the free-to-download Zoom online web and video conferencing service to

\footnotetext{
${ }^{22}$ Ibid.

${ }^{23}$ Campbell, "Understanding the Relationship between Religion Online and Offline in a Networked Society," 81.

${ }^{24}$ Gregory Price Grieve, "A Virtual Bodhi Tree: Untangling the Cultural Context and Historical Genealogy of Digital Buddhism," in Buddhism, the Internet, and Digital Media: The Pixel in the Lotus, ed. Gregory Price Grieve and Daniel Veldlinger (New York: Routledge, 2015), 31.
} 
facilitate meetings. This software can be used on a laptop or desktop, or via an app on an Android or IOS smart phone or tablet. ${ }^{25}$

Once a member of a class or practice group, a user had access to various functions such as participating in the unique class or practice group forum, accessing uploaded documents and media materials, as well as a roster of other group members. Participants logged into a practice or class could select an audio or visual connection, mute or unmute themselves, send chat messages, share documents and their screen, and alternate between a gallery view that tiles all participants as small rectangles and an individual view which switches to a full screen image of whoever is talking. Sessions were controlled by a 'Host,' who had the power to begin and end a session, invite users, record the session, mute or unmute all participants, screen share, and other standard moderator functions. Many of the public classes, such as the 'Open Houses,' were recorded and posted on Ocean's website for viewing by those unable to attend a session, and these recordings did not require login credentials to access. Classes that required memberships were also recorded for later viewing by enrolled course members.

The first 'spring semester"26 on Ocean featured one open class and nine classes restricted based on specific prerequisites. The open class was an Open House, which met for approximately one and a half hours each week and covered diverse topics drawn from Trungpa Rinpoche's body of teachings. The Open House in which I participated had twelve participants from as far afield as Peru, Brazil, and China, as well as four US states (New York, New Mexico, Kentucky, Colorado) and one Canadian province (Nova Scotia). Participants were briefed on the technical use and controls in Zoom by the course's Host, before listening to that evening's talk on the selected topic and some meditation instructions. There was a brief period of quiet sitting meditation where individuals were advised to turn slightly away from their computer screens so as not to be distracted by the moving pictures of other users.

\footnotetext{
25 "Home," Ocean: The Vast Teachings of Chögyam Trungpa.

${ }^{26}$ As of 20 April, 2015, Ocean used the word 'semester' to describe the several month period in which a set of course offerings are run. There was also mention of the upcoming 'fall classes,' but it was unclear if the term 'semester' would remain in use.
} 
As with other meetings on Ocean, users were asked to mute their own microphones unless they wished to talk to prevent background interference from all participants. These are only a few of the technical difficulties and challenges that Ocean users and administrators uncovered through testing and were conveyed to participants as part of the instructions for practice and decorum in the virtual 'shrine room.' To this extent, one's knowledge of using Ocean rather than that born of textual study or meditative practice, served to identify one as a 'senior' student, who might advise new participants on how best to utilize the software and undertake practice online.

Classes that required registration were categorized by the site's administrative team as beginner, which were open to all, intermediate, which required participants to have some familiarity with sitting meditation and Buddhism, and advanced, which required participants to have prior access to Trungpa Rinpoche's vajrayāna teachings. Rather than receiving permission from one's teacher, as is traditional in offline contexts, the advanced courses instituted a system to vet students by asking them to submit information regarding the details of their vajrayana empowerments to the course administrator before they could be enrolled. This manner of adapting traditional means of securing permission in today's digital world has been utilized more broadly within the Shambhala community to control the distribution of certain restricted texts and instructions. ${ }^{27}$ While there were no mandatory fees listed for Ocean's courses, there was a suggested donation of $\$ 10$ per class, made to The Chronicles' PayPal account. As Ocean's administration is run by volunteers, this fee was described as paying for the maintenance of the website as well as a small honorarium for course instructors. ${ }^{28}$ Many of Ocean's first semester classes were taught by wellknown offline teachers in Shambhala, many of whom were former students of Trungpa Rinpoche, such as Larry Mermelstein, Carolyn Gimian, Robert Walker, Clarke Warren, Ellen Mains, and Sherab Chodzin, thus extending offline religious authorities online. As of April 18, 2015, class sizes ranged from one to thirty-seven

\footnotetext{
${ }^{27}$ See, for example, the descriptions of study and practice materials for sale on the websites of the Kalapa Media, the official publisher for the Shambhala mandala:

Kalapa Media, "Publications," accessed 24 February 2017, http://www.kalapamedia.org/SearchResults.asp?Cat=3.

28 "Home," Ocean: The Vast Teachings of Chögyam Trungpa.
} 
members, with most enrollments between eight and fifteen individuals. ${ }^{29}$ At that time, there were also a total of 371 registered users with accounts on Ocean.

The class in which I participated met once a week for approximately one and a half hours over five weeks. Taught by a former student of Trungpa Rinpoche, the course focused on a series of his teachings given in 1973 entitled "Buddhadharma Without Credentials." Class materials consisted of transcripts and audio recordings of the original teachings, as well as supplemental articles and audio recordings that the instructor provided via a private course documents tab. All participants used web-cameras to engage the instructor and other participants and logged in from such disparate regions as Melbourne, Australia, Michigan, Kentucky, Washington, and Colorado. The class began with about fifteen-minutes of sitting meditation, followed by a talk on the week's readings by the instructor. The last thirty to forty-five minutes of the class were open discussions among class participants. It is worth noting that the online forum was rarely used between weekly meetings, with only one user posting several comments on two separate occasions. This is perhaps indicative of users' preference for live interactions over standard chat room, forum, or blog style posting. It may also signal that users' interests were mainly concentrated on receiving instructions and information rather than on social interaction with fellow group members. Thus, while the classroom emerged as a novel interactive sphere of online religious practice and study among live audio-visually connected users, it is unclear to what extent it fulfilled the roll called for by Fordham to stimulate social interaction offline, outside of the online classroom, or if it even stimulated community building in an online space as per Helland's discussion of online religion.

Finally, as of April 18, 2015, there were also two active practice groups on Ocean. The first, a sitting meditation group, met daily for thirty minutes. The second, the Sädhana of Mahämudrā practice group was scheduled to meet on new and full moons. ${ }^{30}$ Similar to the classes and Open House, each of the practices were led by a

\footnotetext{
29 "Classes," Ocean: The Vast Teachings of Chögyam Trungpa, Chronicles Network, accessed 20 April 2015, http://ocean.chronicleproject.com/groups/classes/hierarchy/. 30 "Practice," Ocean: The Vast Teachings of Chögyam Trungpa, Chronicles Network, accessed 20 April 2015, http://ocean.chronicleproject.com/groups/Practices/hierarchy/.
} 
volunteer 'Host,' who maintained control over the virtual 'shrine room.' I participated in the inaugural online practice of the Sädhana of Mabämudrā on Ocean on April 18, 2015. The event, advertised on Ocean, The Chronicles, as well as The Chronicles' Facebook page, was scheduled for 12pm EST, with equivalent times noted for western Europe and the west coast of the United States and Canada. ${ }^{31}$ It was implicit that this time was chosen in order to attract the largest possible audience of participants across North and South America, as well as Europe.

On the day, thirty-two participants from North and South America (no one immediately self-identified as being from Europe) signed on, the majority of whom participated via live web-cameras. The Sädhana text was shared from the Host (Walter Fordham)'s screen and was scrolled through as the ritual practice progressed. To prevent what the Host jokingly referred to as a "cacophony of chaos," the Host muted all of the participants' microphones during the chanting practice. Instead of practicing alongside each other's voices, participants recited simultaneously with an audio recording of the Sädhana of Mahämudrā practice via Windows Media Player that was also shared from the Host's computer. Thus, apart from a brief introduction to Zoom, the liturgy, and a small meeting to solicit user feedback following the practice, there was no direct interaction among participants. While perhaps in the future, there will be no need for individuals to mute their microphones and practice with a recording. At the time, however, communal recitation was mediated through the Host's account.

During my participant observation on Ocean, I heard several telling comments during classes as well as during an organized feedback period following the first practice of the Sädhana of Mahämudrā from individual users sharing their experiences with the space. Following the practice of the Sädhana of Mahämudrā, one participant expressed gratitude at being able to practice this text in a community. Similar remarks on connecting geographically disparate individuals via the web were made during the class I took, when one participant expressed her joy and

${ }^{31}$ Walter Fordham, "Join us for the Sadhana of Mahamudra" email on Ocean listserv, 17 April 2015. 
appreciation at discovering Ocean because of the significant distance between her home and the nearest Shambhala Center. As she described, this distance prevented her from being able to attend and participate regularly in a live Buddhist community. Another participant exclaimed that practicing online was preferable to practicing at a Shambhala Center because it was less distracting, without people moving about around her. Yet another participant expressed a desire to obtain a personal copy of the Sädhana of Mahamudrā text, the possession of which is normally restricted to those who have received the requisite empowerment.

While these comments are not representative of all of Ocean's users, they do contain some salient points for the study of online religion. First, some practitioners were happy to practice in their homes for the sake of convenience or access to a remote community. Second, several users expressed their interest in Ocean because they did not feel comfortable at a religious center and felt they could practice better surrounded by a digital community rather than a live one. Third, some individuals saw the online environment as a means of bypassing traditional authorities, for example as a way to obtain materials otherwise unavailable or requiring a particular initiation to obtain. Such remarks on how individuals value the accessibility to sources and communities, negotiate authorities, and select from among various options for participation are representative of broader shifts in religious life and practice as they move online. In the following section, I will reflect upon these in light of Campbell's concept of networked religion.

For Campbell, networked religion offers an approach to studying how religious practice and life manifest online through taking a network approach where "relationships, identities, and realities are shaped through loosely bounded affiliations established by individual user preferences and connection" rather than traditionally tightly bounded relations established through hierarchies. ${ }^{32}$ One of networked religion's defining characteristics pertains to ideas of accessibility and participation as religion online provides new spaces for individuals to self-select what and what not

\footnotetext{
${ }^{32}$ Campbell, "Understanding the Relationship between Religion Online and Offline in a Networked Society," 83.
} 
to view and take part in. In this way, the internet serves as a sort of "spiritual hub, allowing practitioners to select from a vast array of resources and experience in order to assemble and personalize their religious behavior and belief." 33 Through this process, individuals create "new hybrids of traditional religion as different forms of knowledge and practice are combined to create individualized patterns of spiritual life." ${ }^{34}$ Indeed, this trend toward a pick-and-choose spirituality has been described in religious practice offline more broadly as syncretism, spiritual bricolage, or shopping at the spiritual supermarket. ${ }^{35}$ In regards to spiritual shoppers, for example, Bhikshuni Thubten Chodron writes, "since we have all been raised to be good consumers ... as dharma students and teachers we carry our consumer mentality right into our spiritual practice." ${ }^{36}$ In this way, pick-and-choose spirituality online manifests as the continuation or perhaps even, as an intensification of an offline tendency.

On Ocean, this trend is manifested primarily in users' abilities to select the courses and practices that are most interesting to them and to access a variety of materials and resources on a range of topics. No longer limited by the offerings of physical religious centers or being given a practice or course of study to follow by a religious teacher, Ocean users are free to choose which classes to participate in and can create a personal study and practice schedule based upon an amalgamation of sources and materials off- and online. Moreover, Ocean has no regularly required membership fees or stipulations for users to be members of an offline Shambhala or other Tibetan Buddhist community. Ocean members do not need to provide any religious identification to create an account. Apart from the advanced classes, which require a prior vajrayana empowerment, individuals do not even need to be Buddhist practitioners to engage in the classes or practices on Ocean. Moreover, as there is no obligatory minimum time commitment, users are free to participate in the community once a day, once a week, once a month, or even less. Thus, users are free

\footnotetext{
${ }^{33}$ Ibid., 76.

${ }^{34}$ Ibid., 77.

${ }^{35}$ Bhikshuni Thubten Chodron, "Shopping the Dharma: How do we reconcile our roles as consumers and Buddhist practitioners?" Tricycle: The Buddhist Review 12, no. 2 (Winter 2002), accessed 20 April 2015, http://www.tricycle.com/dharma-talk/shopping-dharma.

${ }^{36}$ Ibid.
} 
to pick and choose from (almost) any of Ocean's resources to use in whichever way they choose.

Campbell describes networked communities as "loose social networks with varying levels of religious affiliation and commitment." ${ }^{37}$ As previously discussed, Ocean's users came from various offline religious affiliations and varying levels of involvement with physical religious communities. According to several dozen public profiles I examined, while some Ocean users are members of Shambhala Centers or meditation groups many others are members of various other Tibetan Buddhist organizations such as Namkhai Norbu's Dzogchen International Community or followers of the $17^{\text {th }}$ Karmapa, Ogyen Trinley Dorje. Others have a range of nonBuddhist religious affiliations or list no affiliation at all. Most users, however, seem to be members of an amalgamation of religious communities on- and offline, thus further illustrating how Ocean plays a role in a broader movement whereby individuals craft their own spiritual lives around a diversity of sources, both off- and online.

Furthermore, Ocean is part of a broader trend whereby internet access facilitates access to virtual religious centers and communities for individuals unable to physically participate in them. As illustrated in the statement above by the participant who remarked on her geographic distance from a nearby Shambhala Center, Ocean facilitated her access to a community she was unable to participate in physically. In this way, Ocean and other sites of online religion are part of broader trends whereby online spaces can facilitate greater accessibility and eliminate geographic boundaries by hosting materials, teaching classes, and offering practice spaces in a virtual environment accessible by anyone with the requisite internet connection. This illustrates the observation by Ostrowski that some individuals

\footnotetext{
${ }^{37}$ Campbell, "Understanding the Relationship between Religion Online and Offline in a
} Networked Society," 68-69. 
participate in online Buddhist communities because of geographical or physiological barriers. $^{38}$

In addition to greater accessibility and participation, Campbell notes that the internet represents a sphere for the renegotiation of religious authority, for a "struggle between traditional sources of religious authority and new authority figures appearing online." 39 Akin to the trend of democratization, which McMahan has noted especially in regards to social and institutional hierarchies, ${ }^{40}$ online spaces of Buddhist practice such as Ocean provide alternative spaces for religious practice that both divest traditional institutional sources of power while reinvesting some of that power in new sources of authority. In the case of Ocean, power becomes partially divested from Trungpa Rinpoche's institutional heir, Shambhala International, and reinvested in other organizations, such as Ocean and its teachers. In other words, online spaces expand the possibility of voices other than those authorized by Shambhala International to act as authorities and preserving the legacy of Trungpa Rinpoche becomes not only the province of Shambhala International, but also of quasi-independent organizations such as The Chronicles and Ocean.

Additionally, power to influence content presented is partially shifted to individual participants on websites such as Ocean as users' input is solicited in the planning of website materials and offerings. As described above, the ideas for Ocean emerged from a town-hall style meeting of fifty-five members of the Buddhist community in Halifax, NS, that posted over two hundred comments and ideas about how such an online space could work and what would be compelling for users. ${ }^{41}$ This interactivity and feedback continues, for example, in the form of a tab on the Classes page that links to a form soliciting suggestions for a class or practice. Other examples include requests for volunteers and beta testers to contribute ideas, skills,

\footnotetext{
${ }^{38}$ Allison Ostrowski, "American Cybersangha: Building a Community or Providing a Buddhist Bulletin Board?" in Buddhism, the Internet, and Digital Media: The Pixel in the Lotus, ed. Gregory Price Grieve and Daniel Veldlinger (New York: Routledge, 2015), 198.

${ }^{39}$ Campbell, "Understanding the Relationship between Religion Online and Offline in a Networked Society," 75.

${ }^{40}$ David McMahan, The Making of Buddhist Modernism (New York: Oxford University Press, 2008): 242.

41 "Exploring the Inner Chronicles," The Chronicles of Chögyam Trungpa Rinpoche.
} 
and suggestions to the development of the website, as well as a uniform request in all of the events for users to contribute comments and suggestions based on their experience. Moreover, unlike in a more traditional Tibetan Buddhist center where a teacher or chant leader normally sits at the front of a space and/or in a higher chair, on Zoom all participants' screens are of equal size and randomly distributed in a grid pattern. This gives the impression at least that all users are equal in their capability for participation. Of course, it must be noted that in both of these examples, participant's agency is circumscribed in that their interactions during classes and practices as well as their suggestions and feedback are ultimately funneled through and vetted by Ocean's administrative team, volunteers, and teachers. In this way, Ocean also provides an example of what Campbell refers to as the internet's capability to introduce new forms of authority, especially in the form of webmasters and site administrators. ${ }^{42}$

While participants have some agentive capacities, most of the authority on Ocean rests with the custodial group, administrators, and class/practice Hosts. Users must request permission to join most classes and if necessary provide evidence of prerequisite training and empowerments. Hosts also can control users via muting, turning off video, and other functions embedded within Zoom. While users can contribute entries in forums and private messages, these are subject to moderation by Ocean's administrators. Moreover, although based on user feedback and comments, ultimately the site developers and designers choose the content and layout. Individual users cannot start new classes or convene sessions on their own. Thus, control on Ocean, like The Chronicles, is ultimately in the hands of the administrators and custodial team. What is important to stress here is that while some of this team, such as many of the teachers, are figures with authority offline, others, such as the volunteer Hosts, do not have any particular position outside of the online context. In this way, Ocean creates new authorities in virtual practice and study spaces, thereby complicating authority in the off/online worlds. This is

${ }^{42}$ Campbell, "Understanding the Relationship between Religion Online and Offline in a Networked Society," 74-75. 
especially true with regards to control over the legacy and teachings of Trungpa Rinpoche.

The organization that Trungpa Rinpoche founded, Shambhala International, is organized today around the metaphor of a mandala, which is described on Shambhala's website as an "energetic pattern of relationships radiating out from a central organizing principle." ${ }^{43}$ This central principle is dually composed of the Shambhala lineage, currently headed by the Sakyong (Trungpa Rinpoche's eldest son) and his wife, the Sakyong Wangmo, and the Shambhala teachings. Ocean, on the other hand, as a subsidiary of the non-profit The Chronicles, is not directly governed by Shambhala International, but by its own board of directors. While many of the board members and class teachers on Ocean are active in Shambhala International's organization, teaching, practice, and other activities, the mission of The Chronicles and Ocean focuses on the life and teachings of Trungpa Rinpoche rather than Shambhala International's broader lineage and teachings. Indeed, it is interesting to note that Shambhala International manages its own platform for online study and practice, Shambhala Online. ${ }^{44}$ While I would not claim that Ocean or The Chronicles are attempts to directly challenge the authority of Shambhala International, their existence, much as that of other communities who claim to continue the teachings of Trungpa Rinpoche such as the Ri-mé Society, Dharma Ocean, or A Place to Sit, complicates Shambhala International's singular authority by setting up parallel structures for the practice and study of Trungpa Rinpoche's teachings outside of Shambhala International. ${ }^{45}$

In this paper, I have illustrated how the shift from information and contentfocused religion online to an ever-increasing number of participatory, accessible, and

\footnotetext{
43 "Shambhala: A Global Community," Shambhala International, accessed 20 April 2015, http://shambhala.org/about-shambhala/shambhala-global-community/.

44 "Shambhala Online," Shambhala International, accessed 20 April 2015, http://shambhalaonline.org/.

${ }^{45}$ Similar to Ocean, Shambhala Online offers opportunities for Buddhist study, practice, and community and is at least partially targeted at individuals who do not live near a Shambhala Center. For example, when one clicks on the "Don't live near a Centre?" tab on Shambhala International's website, one is brought to information about Shambhala Online. A full discussion of this website, however, is beyond the scope of this project.
} 
interactive virtual spaces can be seen in the examples of the Chronicles and Ocean. In this way, Ocean serves as an important site of online religion with the professed goal of enabling access and building community around those who wish to study and practice the teachings of Chögyam Trungpa Rinpoche. Nevertheless, virtual spaces are not isolated from life offline and while they offer possibilities of increased participation, access, and alternatives to offline religious hierarchies, they do not inherently do so. Rather, virtual religious spaces are manifesting as new locales where dynamics of authority and participation that have always characterized religious practice and life extend, shift, and are re-negotiated.

Today, as high-speed internet connections expand and portable internet access via smart phones, tablets, and other devices is increasingly commonplace, the boundaries between time, place, and religious practice on- and offline are dissolving. The very notion of 'being offline' is increasingly challenged as smart phone technologies connect their users $24 / 7$ and in increasingly disparate regions of the earth. Similarly, Ocean collapses many of these boundaries, allowing participants from any time zone or geographic location to connect in the same virtual 'shrine room' for communal study and practice.

Just a decade ago, the thought of more than thirty people from around the world using free software to gather together via their laptops, mobile phones, desktops, tablets, and other devices for a live video-conferenced religious practice would have been close to unimaginable. Today, on websites such as Ocean, this is a daily reality. As the capabilities of the internet expand, the ways in which people use it for the study and practice of religion will also. Moreover, virtual spaces of religious life and practice, like Ocean, will increasingly become online sites of negotiation where questions of authority, participation, and access continue to shift and be renegotiated. Ultimately, as internet capabilities and global interconnections grow and the internet becomes increasingly ubiquitous and integrated into all aspects of daily life, the distinction between life on- and offline will grow increasingly blurry. Thus, scholars should be mindful that as life online and offline become ever-more entangled, understanding religious life and practice will require serious engagement with both physical and virtual spaces. 


\section{Bibliography}

Bhikshuni Thubten Chodron. "Shopping the Dharma: How do we reconcile our roles as consumers and Buddhist practitioners?" Tricycle: The Buddhist Review 12, no. 2 (Winter 2002). Accessed 20 April 2015. http://www.tricycle.com/dharma-talk/shopping-dharma.

Campbell, Heidi A. "Understanding the Relationship between Religion Online and Offline in a Networked Society." Journal of the American Academy of Religion 80, no. 1 (March 2012): 64-93.

The Chronicles of Chögyam Trungpa Rinpoche. Accessed 20 November 2014 and 20 April 2015. http://www.trungpa.com/stories 435.html.

Connelly, Louise. "Toward a Typology and Mapping of the Buddhist Cyberspace." In Buddhism, the Internet, and Digital Media: The Pixel in the Lotus, edited by Gregory Price Grieve and Daniel Veldlinger, 58-75. New York: Routledge, 2015.

Grieve, Gregory Price. "A Virtual Bodhi Tree: Untangling the Cultural Context and Historical Genealogy of Digital Buddhism." In Buddhism, the Internet, and Digital Media: The Pixel in the Lotus, edited by Gregory Price Grieve and Daniel Veldlinger, 93-113. New York: Routledge, 2015.

Helland, Christopher. "Online Religion/Religion Online and Virtual Communities." In Religion on the Internet: Research Prospects and Promises, Religion and the Social Order, edited by D. E. Cowan and J. K. Hadden, 205-223. New York: JAI Press, 2000.

_. "Online Religion as Lived Religion: Methodological Issues in the Study of Religious Participation on the Internet." In "Special Issue on Theory and Methodology." Edited by Oliver Krüger. Special Edition, Heidelberg Journal of Religions on the Internet 1, no. 1 (2005). http://archiv.ub.uniheidelberg.de/volltextserver/5823/.

Lopez, Donald S. Jr. "Introduction.” In A Modern Buddhist Bible: Essential Readings from East and West, edited by Donald S. Lopez Jr. Chicago: Beacon Press, 2002.

McMahan, David. The Making of Buddhist Modernism. New York: Oxford University Press, 2008.

Ocean: The Vast Teachings of Chögyam Trungpa. Accessed 20 April 2015. http://ocean.chronicleproject.com/about/mission/. 
Ostrowski, Allison. "American Cybersangha: Building a Community or Providing a Buddhist Bulletin Board?" In Buddhism, the Internet, and Digital Media: The Pixel in the Lotus, edited by Gregory Price Grieve and Daniel Veldlinger, 191-203. New York: Routledge, 2015.

Sanderson, James and Pauline Hope Cheong. "Tweeting Prayers and Communicating Grief over Michael Jackson Online.” Bulletin of Science Technology \& Society 30, no. 5 (October 2010): 328-340.

Veldlinger, Daniel. "Introduction." In Buddhism, the Internet, and Digital Media: The Pixel in the Lotus, edited by Gregory Price Grieve and Daniel Veldlinger, 1-20. New York: Routledge, 2015. 